Rakenteiden Mekaniikka (Journal of Structural Mechanics), Vol. 53 (2020), No. 2

\title{
Emeritusprofessori Tapio Salmen muistoa kunnioittaen
}

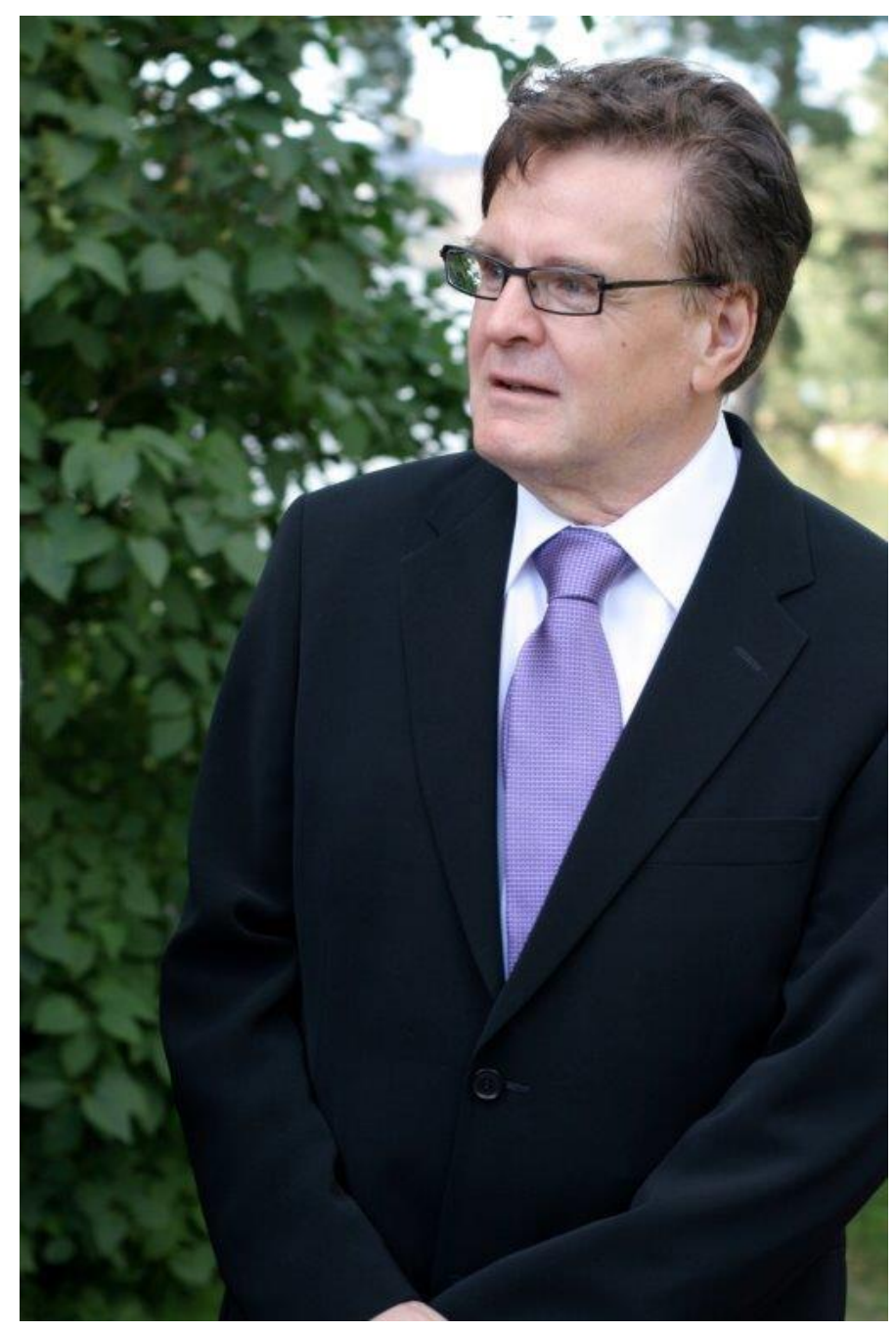

Teknillisen mekaniikan emeritusprofessori Tapio Ilmari Salmi menehtyi vaikeaan sairauteen 18. päivänä heinäkuuta 2018 Tampereella 72 vuoden ikäisenä. Hän oli syntynyt 28. helmikuuta 1946 niin ikään Tampereella.

Tapio Salmi kirjoitti ylioppilaaksi Tampereen lyseosta keväällä 1965. Tämän jälkeen hän aloitti opinnot Tampereen teknillisessä korkeakoulussa (TTKK) ja valmistui diplomi- 
insinööriksi 1974. Tapio toimi TTKK:n mekaniikan assistenttina 1973-1985 ja hoiti Oulun yliopiston teknillisen mekaniikan ja lujuusopin apulaisprofessuuria 1983-85 ja tähän virkaan hänet nimitettiin 1985. Oulun yliopiston rakenteiden mekaniikan ma. professorina hän toimi 1998-2000. Tampereen teknillisen yliopiston teknillisen mekaniikan ja lujuusopin professorina hän aloitti 1. päivä syyskuuta 2000 ja tästä toimesta hän jäi täysin palvelleena eläkkeelle 1. maaliskuuta 2011.

Tapio oli persoonaltaan positiivinen niin työyhteisössään kuin vapaa-ajallaankin. Hän oli kaikessa tekemisessään tinkimättömän oikeudenmukainen ja reilu alaisiaan ja kollegoitaan kohtaan. Tapio myös johti omalla esimerkillään ja otti nuoremmat kollegat huomioon tasavertaisina työtovereina antaen heille suoraa mutta kannustavaa palautetta niin teknillisen mekaniikan tutkimuskysymyksissä kuin opettamisessa. Tapiossa kiteytyi perinteinen mestari-kisälli-toimintamalli, ja hän jaksoin väsymättä ohjata nuorempia kollegoja systemaattisessa ongelmanratkaisussa ja pedagogisissa kysymyksissä. Tapiolla oli harvinainen kyky luoda ympärilleen innostunut ilmapiiri, ja kaikessa mihin hän ryhtyi, oli "tekemisen meininki". Hänellä oli myös poikkeuksellisen vahva näkemys asioiden tärkeysjärjestyksestä, ja sitä hän omalla urallaan noudatti.

Tapio oli tuottelias suomenkielisen oppimateriaalin kirjoittaja. Hän kirjoitti lukuisia mekaniikan oppikirjoja teknillisen mekaniikan kaikille tasoille. Kirjojen lisäksi iso osa materiaalia oli luentomonisteina sekä mittavana määränä laskuharjoituksia ja muuta opetusmateriaalia. Hänellä oli sydämen asiana jatkuvasti kehittää materiaalia paremmaksi erityisesti perusmekaniikan kursseille. Tuhannet suomalaiset kone- ja rakennusinsinöörit ovat saaneet korkeatasoista mekaniikan opetusta, joka on perustunut Tapion kehittämään materiaaliin. Hyvin harvan professorin työpanoksella on ollut niin suuri yhteiskunnallinen vaikuttavuus kuin mitä Tapion elämäntyöllä oli.

Tapio jatkoi eläkkeelle jäätyäänkin aktiivista yhteydenpitoa yliopistomaailmaan, ja vielä vuoden 2018 kevääksi pyysimme häntä luennoitsijaksi mekaniikan opintojaksolle, mutta tämä jäi toteutumatta.

Vapaa-ajallaan Tapio harrasti monia asioita, joista työyhteisöä kosketti erityisesti jalkapallo, sillä hän oli mukana järjestämässä TTKK:n ja sittemmin TTY:n vuosittaista laitosten välistä jalkapalloturnausta vuodesta 1974 alkaen. Teknillisen mekaniikan laitoksen viikoittainen jalkapallovuoro Nalkalan kentällä oli sekin Tapion organisoima. Historia ja viime vuosina erityisesti Suomen historia kuului Tapion mielenkiinnon kohteisiin.

Taide oli myös lähellä Tapion sydäntä ja hänen öljyväriteoksensa pariisilaismaisemasta on esillä Hervannassa Rakennustalon M-käytävällä.

Sami Pajunen, Reijo Kouhia, Jari Mäkinen, Antti-Jussi Vuotikka ja Tero Frondelius 